\title{
Use of Community Building Web Technologies in Libraries: A Study of Twitter in American Libraries
}

\author{
V Vishwa Mohan \\ Department of Library \& \\ Information Science, \\ Osmania University, \\ Hyderabad, A.P., India
}

drvvm321@yahoo.com

\author{
Achala Munigal \\ PG College of Science, \\ Saifabad, \\ Osmania University, \\ Hyderabad, A.P., India
}

AchalaMunigalRao@gmail.com

\begin{abstract}
Dissemination of knowledge at the speed of thought is the need of the hour. Hence the libraries and information centers should be the forerunners in utilizing the latest technologies, especially information communication technologies, to serve the indispensable information needs of the user community. They should also act as facilitators in knowledge sharing. It is the community building technologies of the Web 2.0 that need to be utilized to the optimum extent by the libraries to develop scholarly communities. The present study is aimed at exploring the state-of-the-art of the use of Twitter by the modern libraries to disseminate information/knowledge to their users. The objectives of the study are to find out whether Twitter is used for social networking in the libraries of the United States of America (U.S.)? Which way libraries in U.S. are using Twitter? What information is communicated through Twitter? Whether U.S. library Twitter accounts have any followers? The methodology applied for the study is a survey of the entire universe of Twitter accounts of U.S. libraries that are found in websites like Lindy Brown's blog. The findings of the study are: U.S. libraries use Twitter to provide alert and current awareness services to their users. Library Twitter accounts are not followed by encouraging number of followers.
\end{abstract}

Keywords: Community Building, Twitter, Libraries, Web Technologies, Web 2.0

[Note: numbers in brackets refer to the list of access through Twitter listed at the end of the paper.]

\section{Introduction}

Dissemination of knowledge at the speed of thought is the need of the hour. Hence the libraries and information centers should be the forerunners in utilizing the latest technologies, especially information communication technologies, to serve the indispensable information needs of the user

Material published as part of this publication, either on-line or in print, is copyrighted by the Informing Science Institute. Permission to make digital or paper copy of part or all of these works for personal or classroom use is granted without fee provided that the copies are not made or distributed for profit or commercial advantage AND that copies 1) bear this notice in full and 2) give the full citation on the first page. It is permissible to abstract these works so long as credit is given. To copy in all other cases or to republish or to post on a server or to redistribute to lists requires specific permission and payment of a fee. Contact Publisher@InformingScience.org to request redistribution permission. community. Libraries of the digital age should not be lagging behind in using the latest technologies. Libraries of the Internet age should not only disseminate knowledge that is gathered by them, they should also act as facilitators in knowledge sharing. Knowledge sharing is possible when knowledge sharing communities are developed. It is the community building technologies of the Web 2.0 that need to be utilized to the 
optimum extent by the libraries to develop scholarly communities. The present study is aimed at exploring the state-of-the-art of the use of Twitter by the modern libraries to disseminate information/knowledge to their users in United States of America (U.S.)

Twitter [1] (n.d.) was created in March 2006 by Jack Dorsey and launched in July of the same year. Twitter availability is multilingual, including Dutch, English, French, German, Indonesian, Italian, Japanese, Korean, Portuguese, Russian, Spanish, Turkish, Chinese, Hindi, Tagalog and Malay. It is felt that Twitter as communication and community building tool on the web is gaining immense popularity. Even the President of U.S., Barack Obama, uses Twitter [2]. Therefore it is felt that there is a need to find out whether the key stakeholders, in the knowledge societies, like library and information centres are also using these technologies to ensure effective communication amongst their users. Are they building scholarly communities, is a subject of greater interest and significance.

Being one of the advanced countries U.S. is known for its faster application of the latest technologies. Therefore a study is conducted to find out the use of Twitter in U.S. libraries. How many libraries are using, whether they have any followers and what services they provide?

\section{Significance of the Study}

Being a survey, the study deals with the situations that are prevailing in the contemporary period, in addition to reporting the present state of use of Twitter in the libraries in U.S., it would also have historical significance in future as a record for posterity. The study gives ideas on how libraries can use Twitter effectively in their library. Besides, the study, by reporting the state of the use of Twitter, would also impress libraries world over upon the use of social tools on the web to provide effective services to their users.

\section{Objectives}

The objectives of the study are to find out:

- Whether Twitter is used for social networking in U.S. libraries.

- What are the possible ways in which the U.S. libraries are using Twitter.

- What information is communicated through Twitter by the U.S. libraries.

- Whether U.S. library Twitter accounts have any followers.

\section{Hypotheses}

1. U.S. Libraries are active in using Twitter to develop their user community.

2. U.S. Libraries use Twitter to provide alert and current awareness services to their users.

3. Library Twitter accounts are not followed by encouraging number of followers.

\section{Methodology}

The methodology applied for the study is a survey method. It is a survey of the entire universe of Twitter accounts of U.S. libraries on the web that are found in website of Lindy Brown's blog. A federated search is conducted using different sources such as Twellow [3], Twitterleague [4], David Lee King [5], Paul Stainthorp [6], and blog of Lindy Brown from these sources information about U.S. libraries' Twitter accounts were retrieved. Twellow listed 4332 accounts from all countries, Twitterleague listed 629 accounts from all countries, David Lee King lists only nine 
accounts, Paul Stainthorp in his blog lists exclusively about 100 UK libraries on Twitter and Lindy Brown 877 accounts are all U.S. libraries. Twellow's listing includes libraries and librarians, as well as unrelated accounts like the one related to the 'wine library' which is the Internet's leading discount wine retailer. Therefore it is found that Lindy Brown is more relevant and exhaustive listing of Twitter accounts of U.S. libraries. Necessary data is gathered from all these 877 accounts. However Lindy Brown's listing is purely alphabetical, hence it does not present the order of Twitter accounts based on the number of followers. Therefore information from Twellow was also utilized to extract data relating to number of followers. Twitterleague is not taken into consideration for this study as it did not contain updated data of the Twitter accounts.

\section{Scope}

Study covers the Twitter accounts of U.S. libraries only and it confines itself to the number of followers and type of services that are provided by these libraries. Further the study does not include South America or Canada.

\section{Analysis}

The data collected from the web-sources about the Twitter accounts of U.S. libraries presents an encouraging picture that as many as 877 (as on 1/28/2012) U.S. libraries are using Twitter to build their user communities. It shows that the U.S. libraries have right perception of the need for utilizing community building technologies and tools that facilitate speedy communication.

However when it comes to the followers of these Twitter accounts the situation is encouraging only to certain extent. It is only the Library of Congress [8] that has 306,524 followers as on 28 November 2011 and it is quite interesting to note that the number of followers is increasing at a commendable rate. The twitter account of the same library on the very next day has increased by 309 at 306833 followers on 29 November 2011 and on 11 March 2012 it is up by 38260 at 344784 followers.

This clearly indicates that even Twitter accounts of libraries have hundreds of thousands of followers and there is marked increase in the number of followers.

The New York Public Library [9] has as many as 175,128 followers. This might be an indication that if a library renders useful services or provides significant and current information, it will certainly have large following. But these libraries happen to be world's largest library and library of national level importance respectively. 


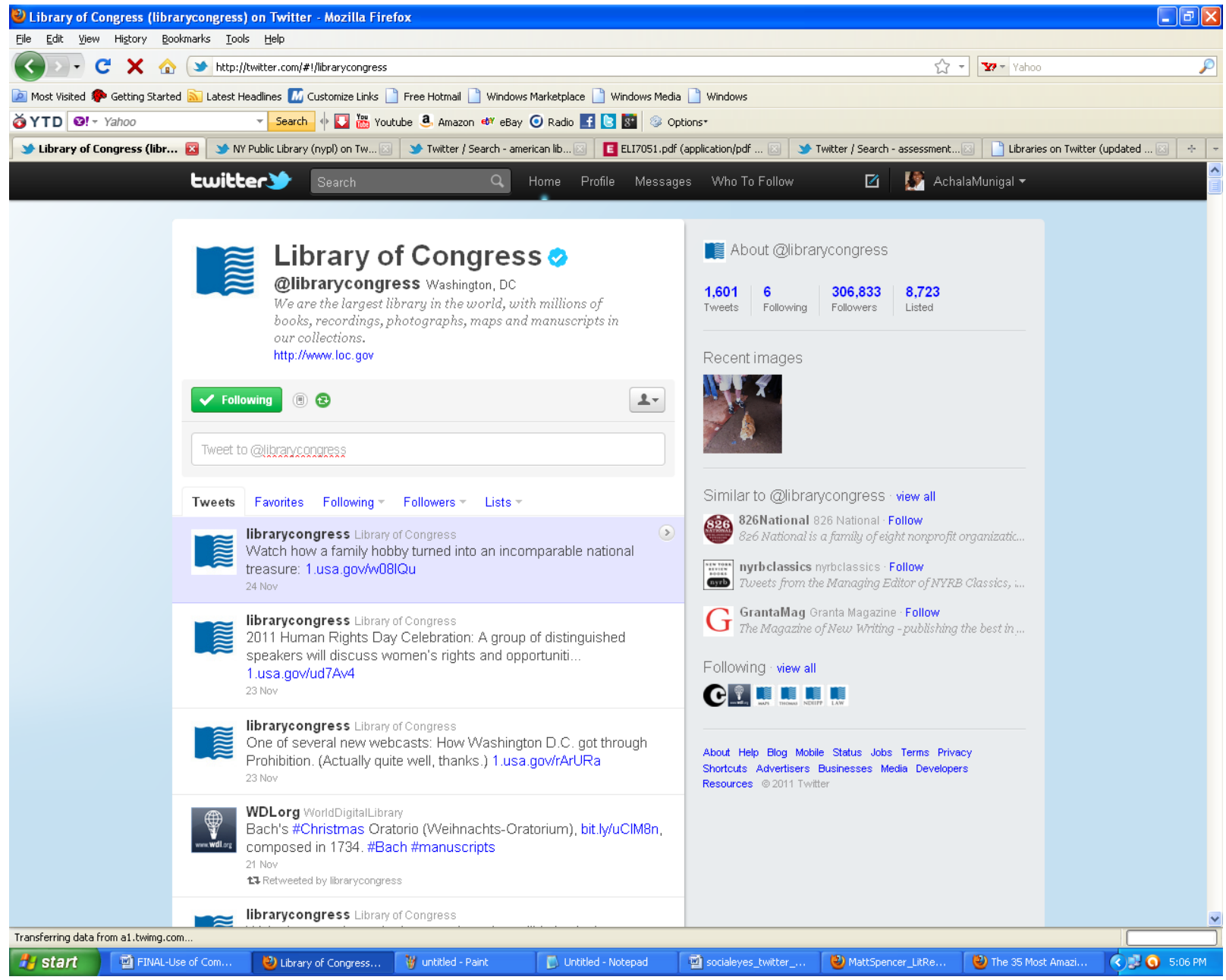

Figure 1: The screenshot of Library of Congress on Twitter (Source: http://Twitter.com/\#!/librarycongress 29.11.2011 5:07 pm IST) 


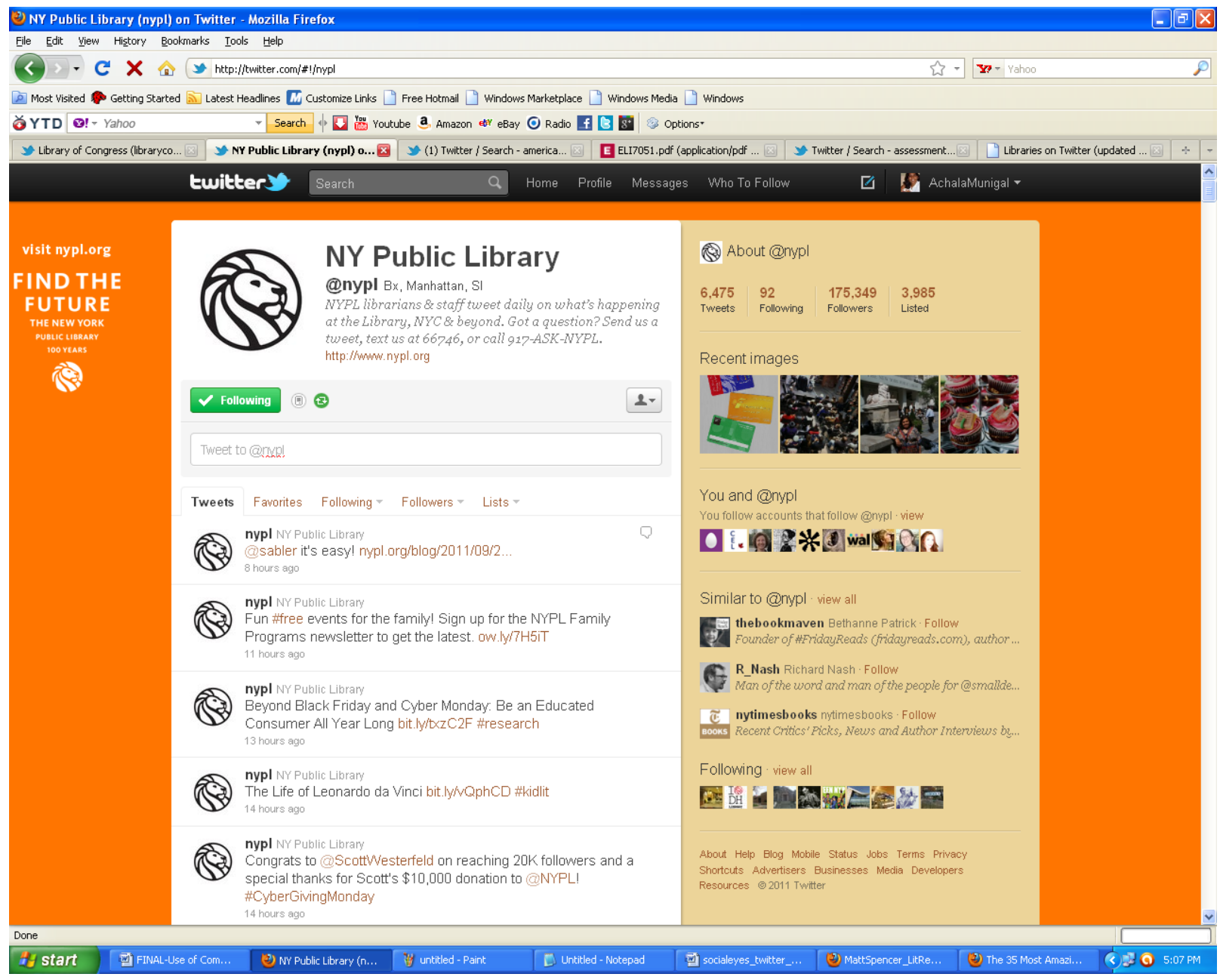

Figure 2: The screenshot of New York Public Library on Twitter.

(Source:http://Twitter.com/\#!/nypl29.11.2011 5:07 pm IST)

When it comes to libraries that rank next to these libraries, they have 9027 number of followers for United States Department of Agriculture's National Agriculture Library (USDA NAL) [10], and Houston Library [11] has 7,216 Followers as on 28.11.2011. It is surprising to note that the Internet Public Library (IPL) http://www.ipl.org/ has 1,102 followers only as on 28.11.2011 at $7: 15 \mathrm{pm}$ IST and it is not listed under "Internet Public Library" or "IPL" on Twitter but is listed as "theipl" at https://Twitter.com/\#!/theipl, which is not known to people at large. Further it is not listed in Lindy Brown's blog may be as it is not a conventional library but a virtual library.

However about $50 \%$ of the libraries have less than 1000 followers. There is also incidence of some of the libraries having zero followers and few accounts are listed in a few websites but on checking have been found deleted.

\section{Use of Twitter in U.S. Libraries}

Twitter has become an integral communication tool along with other popular social networking technologies that are now used in libraries and displayed on their homepages. As mentioned above, libraries provide alert services, reference services, short newsletters and other services as presented below. The data also indicate that majority of the libraries are providing alert services. 
A considerable number of libraries are rendering reference service. The following presents the ways in which some of the libraries are using Twitter:

1. Twitter as another communication tool: Librarians are using Twitter as another communication tool to communicate with their patrons. The following illustrates the same.

nypl NY Public Library

Qnychypnosis if you can't reach us by phone contact us by chat or email nypl.orgiask-nypl for help with your account $14 \mathrm{Nov}$

(Source: New York Public Library at http://Twitter.com/\#!/nypl29.11.2011 5:47pm IST)

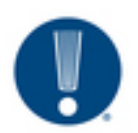

FPL_Library Fayetteville Library

I posted 18 photos on Facebook in the album "An Evening With

Geraldine Brooks Event" fb.me/14iQuqiwD

20 Now

(Source: Fayetteville Library at http://Twitter.com/\#!/fpl_library 30.11.2011 5:47pm IST)

021 201. Harvard Harvard University

[1]5: We invite you to keep up with Harvard happenings, on campus \& around the world, by visiting our Facebook page. hvrd.me/qWQZ1R 27 Nov

(Source: Harvard University at http://Twitter.com/\#!/Harvard 29.11.2011 6:23 pm IST)

\section{LibraryAmerica Library of America}

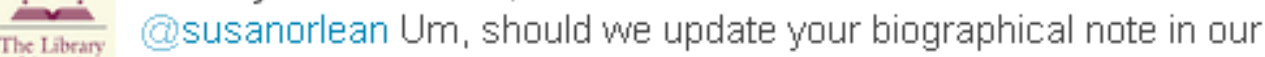

of Amstica anthology?

18 Nov

(Source: Library of America http://Twitter.com/\#!/LibraryAmerica 30.11.2011 7:13pm IST)

2. Library announcements : Library related information is updated to patrons as well a special events to be held, exhibitions, new book arrivals, and author visits are posted so that patrons are aware of current or future events.

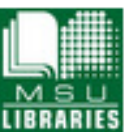

msulibraries MSU Libraries

New Exhibit: The Art of Mass Production \& Trends in 21st Century

Industrial Design. 4th fl. West until Jan. 2, 2012 - bit.ly/uOMEpb

29 Noy

(Source: Michigan State University Libraries at http://Twitter.com/\#!/msulibraries30.11.2011 6:33pm

IST)

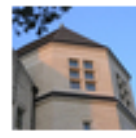

kstatelibraries K-State Libraries

Interlibrary Services requests made after Nov. 22 will not be

processed until Nov. 28.

23 Nov

(Source: K-State Libraries at http://Twitter.com/\#!/kstatelibraries (30.11.2011 6:49 pm IST) 


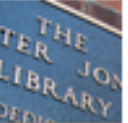

mblibrary mblibrary

New Resources Lists: see all the DVDS-VHSs the library owns, or all the Audiobooks the library owns. Catalog $>$ Resources

Lists $>$ Public Lists

17 May

(Source: Moses Brown School at http://Twitter.com/\#!/mblibrary 29.11.2011 6:13 pm IST)

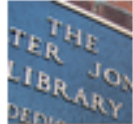

mblibrary mblibrary

SciFi readers start your summer list: "The stars of modern SF pick

the best science fiction" from The Guardian http://bit.ly/kzkw9O

23 May

(Source: Moses Brown School at http://Twitter.com/\#!/mblibrary 29.11.2011 6:14 pm IST)

3. Send alerts: Patrons subscribing to Twitter account of the libraries receive notices regarding material requested which have arrived at library rather than existing technologies like email and mobile.

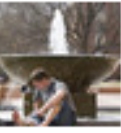

OkStateLibrary OkStateLibrary

Reminder: "The Way to Rainy Mountain" book discussion is today at

3 p.m. in the Browsing Room. bit.ly/nOyPpo

2 Nov

(Source: Oklahoma State University Libraries at http://Twitter.com/\#!/OkStateLibrary30.11.2011

$6: 31 \mathrm{pm}$ IST)

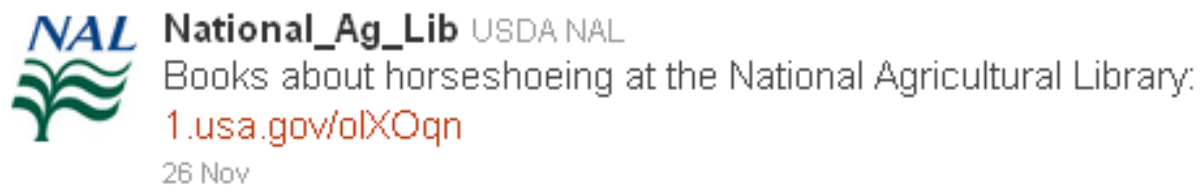

(Source: National Agricultural Library athttp://Twitter.com/\#!/National_Ag_Lib 29.11.2011 6:20 pm IST)

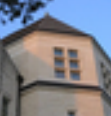

kstatelibraries K-State Libraries

You can keep an eye on our latest psychology acquisitions by

checking our new books feed - it's updated weekly! owl.li/7HKWW

29 Nov

(Source: K-State Libraries at http://Twitter.com/\#!/kstatelibraries 30.11.2011 6:48 pm IST)

\section{Reference Service:}

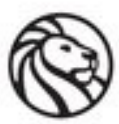

nypl NY Public Library

Fact of the Day: 2.4 Billion... pounds of sweet potatoes were produced in US in 2010. More Thanksgiving facts: ow ly/7CqVT \#ASKNYPL

23 Nov

(Source: New York Public Library at http://Twitter.com/\#!/nyplReference 29.11.2011 5:33pm IST) 
$\cdots \quad$ LibraryAmerica Library of America

(Source: Library of America http://Twitter.com/\#!/LibraryAmerica 30.11.2011 7:23pm IST)

5. TwiReference: Reference queries on Twitter posted by patrons that library staff can get back with information requested. Clickable shortened URLs are posted where information is accessed.

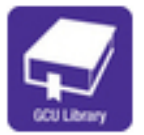

gculibrary GCU Library

Reference question of the day. What is this symbol * (Asterisk) used

for?

28 Jul

(Source: Grand Canyon University Libraryat http://Twitter.com/\#!/gculibrary 29.11.2011 5:55pm IST)

6. Customer Service: Librarians view Twitter as open lines of communication; another opportunity to extend customer service.

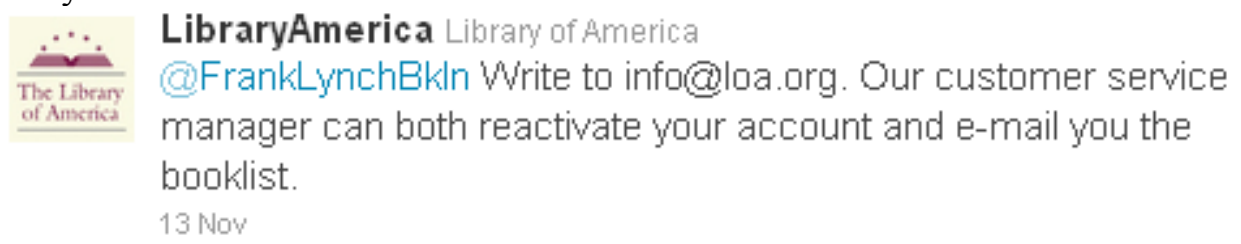

(Source: Library of America http://Twitter.com/\#!/LibraryAmerica 30.11.2011 7:18pm IST)

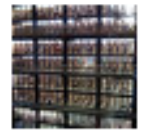

\section{NYULibraries NYU Libraries}

BobCat and E-Journals A-Z currently experiencing problems

goo.gl/fb/Rornm

22 Nov

(Source: NYU Libraries at http://Twitter.com/\#!/NYULibraries 30.11.2011 6:44 pm IST)

7. Short newsletter: Twitter gives a short, crisp and precise newsletter or it acts as a short 140 character write up with shortened URL to build patron interest to draw them into reading a bigger newsletter posted on their website or blog.

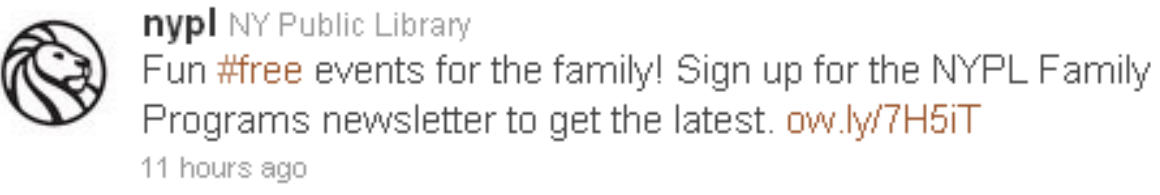

(Source: New York Public Library at http://Twitter.com/\#!/nypl29:11.2011 5:25pm IST)

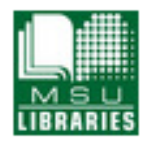

msulibraries Msu Libraries

library news: This Week in the Main Library - Michigan's Energy

Future Presentation and Espresso Demo bit.ly/sFbR7p

28 Nov

(Source: Michigan State University Libraries at http://Twitter.com/\#!/msulibraries 30.11.2011 6:37pm IST)

\section{Library Orientation Program:}




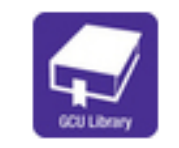

gculibrary GCU Library

Hello and welcome to all the incoming ground students! The Library

is open 7 days a week - Sun thru Thurs until 10pm. Stop on by!

25 Aug

(Source: Grand Canyon University Library at http://Twitter.com/\#!/gculibrary 29.11.2011 5:56pm IST)

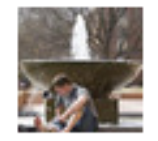

OkStateLibrary OKStateLibrary

Library 101 tours are offered today at 10 a.m. \& 2 p.m. Don't miss

them! bit.ly/kn.JfW

21 hours ago

(Source: Oklahoma State University Libraries at http://Twitter.com/\#!/OkStateLibrary 30.11.2011 6:31pm IST)

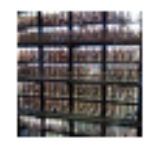

\section{NYULibraries NYU Libraries}

New to Bobst? Take a Video Tour goo.gl/fb/lMXQ2

8 Nov

(Source: NYU Libraries at http://Twitter.com/\#!/NYULibraries 30.11.2011 6:47 pm IST)

9. TwiFeed gives Feedback: Suggestions and opinions are generated or gathered regarding new services introduction or changes to existing policies quickly, and easily through Twitter.

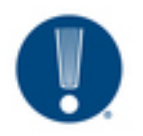

FPL_Library Fayetteville Library

It's Survey Week at FPL. Please take the time to tell us how we're

doing. You can choose from short to long... fb.me/1iSi5DnDo

7 Nov

(Source: Fayetteville Library at http://Twitter.com/\#!/fpl_library 30.11.2011 7:07pm IST)

\section{Polling}

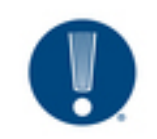

FPL_Library Fayetteville Library

Vote for the best books of the year at the 2011 Goodreads Choice

Awards! fb.me/l2oRKCtz

5 Nov

(Source: Fayetteville Library at http://Twitter.com/\#!/fpl_library 30.11.2011 7:09pm IST)

\section{Provision of links to the library resources:}

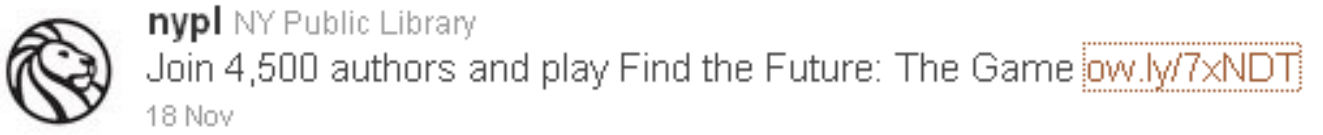

Gaming apps for iphone \& android. Finish your adventure online, where the Artifacts you found at the Library can help you write and publish your own world changing epic. http://game.nypl.org/how to play\#/

(Source: New York Public Library at http://Twitter.com/\#!/nypl29:11.2011 5:25pm IST) 
12. Community Information Services: Some of the Libraries are providing Community Information Services.

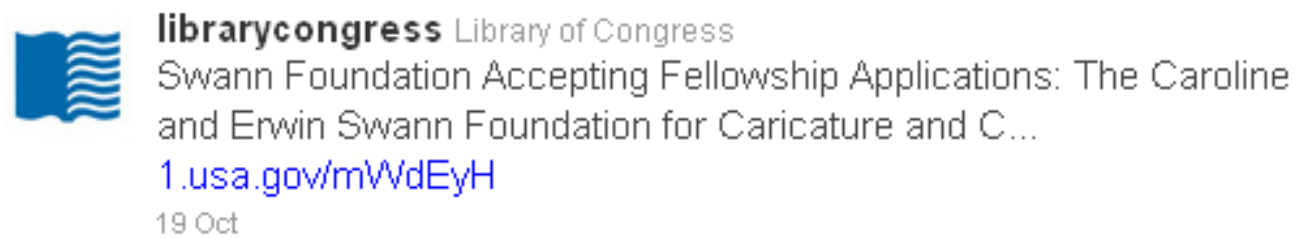

(Source: Library of Congress at http://Twitter.com/\#!/librarycongress 29:11.2011 8:25pm IST)

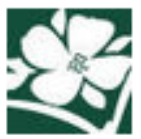

dekalblibrary DeKalb Co Library

Bring your sensitive documents to 3720 Leroy Scott Drive, Decatur

for free on-site shredding \& recycling this Saturday. bit.ly/s9rpnC

17 Nov

(Source: DeKalb Co Library at http://Twitter.com/\#!/fhulibrary 29.11.2011 5:51pm IST)

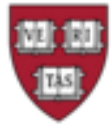

Harvard Harvard University

On this weekend of football rivalries, two Harvard videos from

alums who played football: hvrd.me/uBftzs

27 Nov

(Source: Harvard University at http://Twitter.com/\#!/Harvard 29.11.2011 6:23 pm IST)

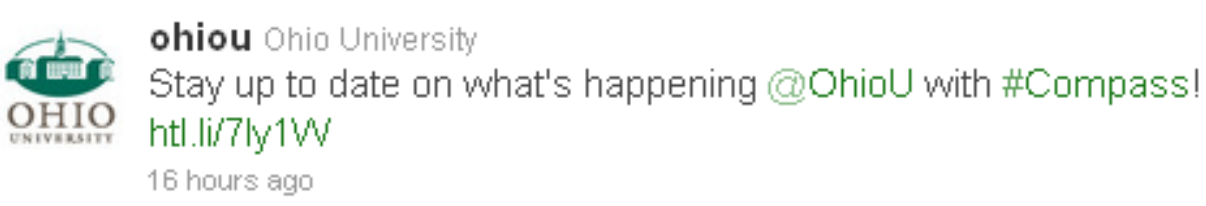

(Source: Ohio University at http://Twitter.com/\#!//ohiou 30.11.2011 6:40 pm IST)

13. Short messages can tell people about events such as readings, podcast, webcast, and lectures: Typing a brief message about a special reading or lecture can help get the word out. You can even send updates of the day to let people know how many are attending.

librarycongress Library of Congress

One of several new webcasts: How Washington D.C. got through

Prohibition. (Actually quite well, thanks.) 1.usa.govirArURa

23 Nov

14. Cataloging and tagging: Links to library WebPACs are provided to the users. This would eliminate the process of visiting library website. The users can directly access WebPACs. And also it facilitates the users to tag the resources. \# hash tags help create groupings

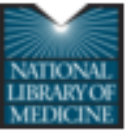

NLM_SIS NLM SIS

RT@nlm_osp: The National Library of Medicine(R) (NLM(R)) adopted the $2012 \mathrm{MeSH}$ vocab for cataloging on Nov 21, $2011 \mathrm{ow} . \mathrm{ly} / 7 \mathrm{C} 5 \mathrm{Hd}$ 23 Nov 
(Source: National Library of Medicine at http://Twitter.com/\#!/search/Cataloging\%20library

29.11.2011 4:27 pm IST)

15. Conference information: Twitter feeds provide information on conferences, registration, deadlines, speakers, webinars, and accommodations without having to visit the hosting website. Librarians can also connect with librarians locally who are going to same conference, so that they get better discounts in accommodation.

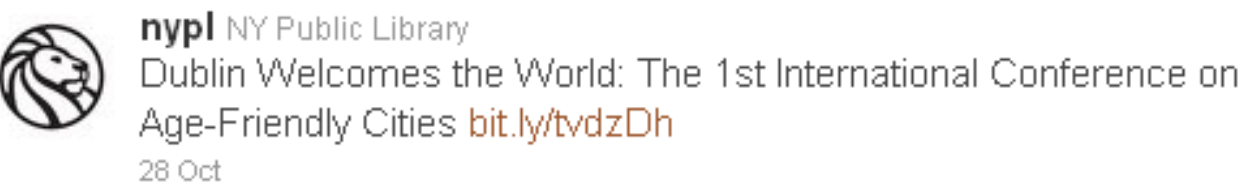

(Source: New York Public Library at http://Twitter.com/\#!/nyplConference 29.11.2011 5:47pm IST)

\section{Job}

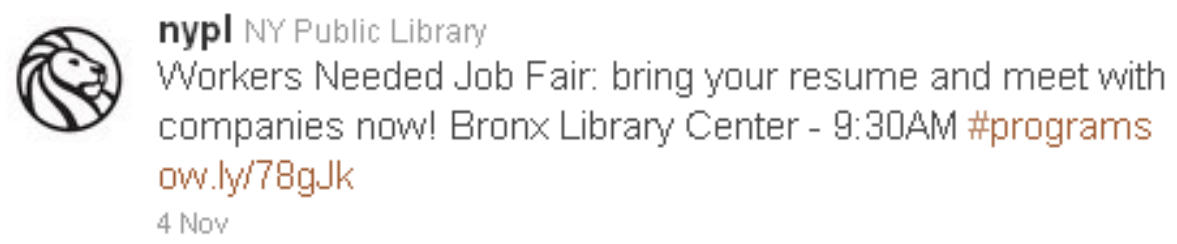

(Source: New York Public Library at http://Twitter.com/\#!/nyplJob 29.11.2011 5:45pm IST)

\section{Crisis or emergency communication tool}

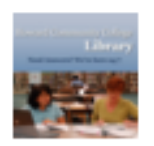

howardcclibrary Howard CC Library

Hurricane Preparedness - Enoch Pratt Free Library bit.ly/qqlc.JG via

(c) addthis

25 Aug

Community information services/crisis management/emergency preparedness

(Source: Howard CC Library http://Twitter.com/\#!/howardcclibrary 29.11.2011 6:10 pm IST)

\section{Education Tool}

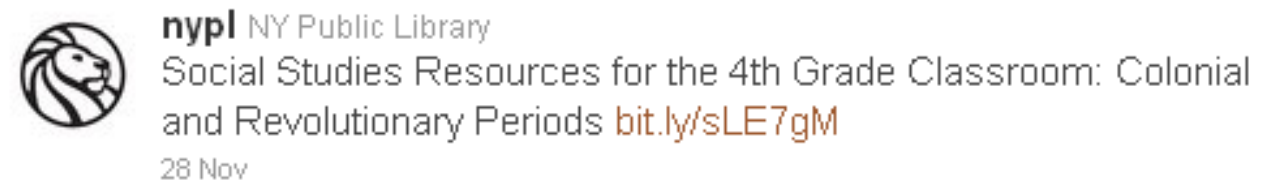

(Source: New York Public Library at http://Twitter.com/\#!/nyplBibliography 29.11.2011 5:28pm IST)

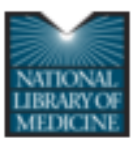

NLM_SIS NLM SIS

Lessons About Bioscience (LAB) Challenge: submit experiments for

k-12 related to health \& life science LAB.challenge.gov

18 Now 
(Source: National Library of Medicine at http://Twitter.com/\#!/NLM_SIS 29.11.2011 6:17 pm IST)

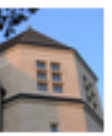

kstatelibraries K-State Libraries

Short Cuts: Check out these Cite Sites! owl.li/1fTCj5

20 hours ago

(Source: K-State Libraries at http://Twitter.com/\#!/kstatelibraries 30.11.2011 6:47 pm IST)

\title{
19. Personalized one to one Communication:
}

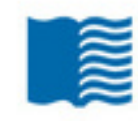

\author{
librarycongress Library of Congress \\ (QDawsonCityYukon Aw, thanks! :) \\ 15 Nov
}

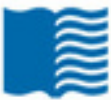

librarycongress Library of Congress

(c)DeliaCabe :)

15 Nov

(Source: Library of Congress at http://Twitter.com/\#!/librarycongress 29.11 .2011 8:21 pm IST)

20. Marketing/Public Relations role: Twitter was mostly used for business applications but is now adopted by librarians as it is an excellent way for libraries to grow their online presence and profile.

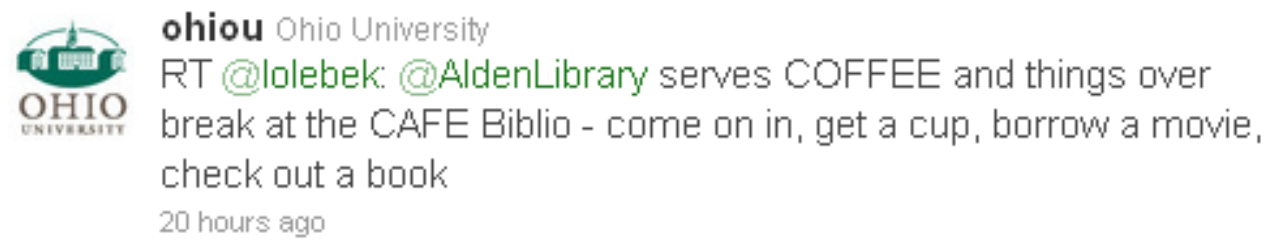

(Source: Ohio University at http://Twitter.com/\#!/ohiou 30.11.2011 6:38 pm IST)

\section{RSS Feeds:}

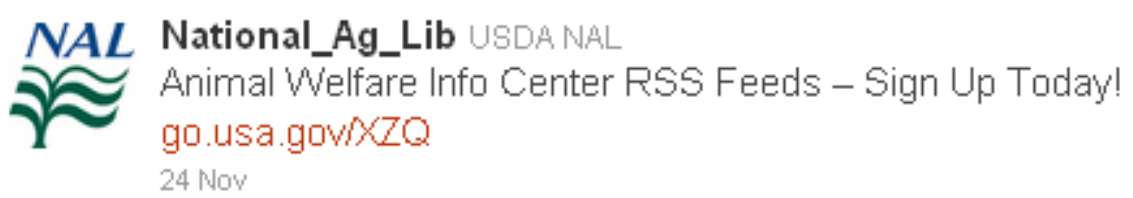

(Source: National Agricultural Library at http://Twitter.com/\#!/National_Ag_Lib 29.11.2011 6:21 pm IST)

22. Send computer alerts: Whether someone's allotted time on the computer is about to end or if several computers have suddenly become available, let users who are waiting know. Using Twitter to broadcast messages to each public computer such as, "You have 5 minutes left on this computer. Please save your work and log off now" or "The library will be closing in 15 minutes." http://www.techsoupforlibraries.org/?q=node/85 (29.11.2011 6:21 pm IST)

\section{librarycongress Library of Congress}

The Library's Jefferson Building will close at 3 p.m. next Tuesday, Nov. 22. loc.gov/today/pr/2011/... 
(Source: Library of Congress at http://Twitter.com/\#!/librarycongress 29.11.2011 4:46pm IST)

Rick Reo [12], Web Source entitled 100 Ways to Use Twitter In Your Library [13], and Brian Mathews [14] are of the opinion that libraries can use Twitter in various ways. The following are the extracts from the above sources:

- Use of Twitter as an assessment tool: For example, subscribe to a handful of patrons or students, in return they should follow you also. By tweeting, you can learn about such things as what services are being used the most in the library.

- TwiInsPad: Twitter Instant Notepad: Great ideas can be jotted down on the move as most of mobiles/smartphones have this Twitter feature.

- Patrons can ask questions about specific materials. Let your patrons know if you have a certain book or article they are looking for or let them know where they can find it. This also will keep up the community feeling that your library is looking for.

- Search Twitter for references to the ALA (American Library Association): If it's something there you can respond to then go ahead. If it's not something in your area, then pass along the information.

- Networking: Twitter is most useful to network with other librarians, libraries, libraryaffiliated organizations, and publishers. Since all librarians and libraries are not on Twitter, it has a limited reach.

- Promote the library: Using Twitter can help promote your library and the programs offered. Tweet your friends and family about what's happening.

- Suggestion box. Cynthia Johnson, Head of Reference, University of California, Irvine. Additionally, Johnson explained how her expectations of user's needs were far different than the reality. After setting up the library's Twitter account, Johnson watched as it evolved into a virtual suggestion box. Johnson welcomed this unforeseen use of Twitter. Despite the suggestion box that had lived at the library for years, user feedback flooded the library's Twitter account.

- Create alerts for specific groups: Announce news and events for specific groups like children, book clubs, and teens

- Q \&A Twitter sessions: Instruction sessions or clarifications regarding new membership for public libraries are conducted on Twitter.

- Use Twitter to point out highlights on library websites: Point out specific topics of interest on the Library website. Everything from special links to holiday hours.

- Appointing new Library Staff: When interviewing someone for a library job, librarian can check to see if they tweet. One can know more about the person by checking their Twitter feed similar to Googling them to check their web presence or check their blog.

- Chronicle extended library visits: This is being used by a number of university libraries when a student might arrive at the library at 4 p.m. and might not leave until 10 a.m. the next day he updates his/her followers periodically on the progress of his assignment.

- Connect and Keep in touch: Librarians get in touch with other librarians on a local, state, national, regional, and international level. Twitter makes it easy to network, collaborate, share information, find out what others are doing and update the world on self status. 
- Find contacts working on similar projects. Stumped about a presentation or project you are working on? Twitter is a great way to find others that have had a similar problem and get a swift response.

- Find out what other schools and libraries are doing around the world: Get ideas on how other libraries all over the globe are using Twitter effectively in their library.

- Get to know colleagues: Most of us are so busy in our lives and networking with far off personal and professional friends that we tend to ignore those working with us. Reading posting on Twitter about his/her life, likes and dislikes. Librarians may get to know or realize that they may have more in common with their colleagues than earlier thought.

- Identify experts in a specific area: Twitter can be an additional tool to find out who's talking about subjects that interest your patrons.

- Internal updates: To some extent Twitter can be used for internal updates if it is for closed group. Or sending private message to only one specific person. Use "d" to send a direct message to someone [for example: "d sarahlib great to see you on Twitter!"]

- Overactive account: Following the thought processes of emerging tech trend thinkers. Ex - Robert Scobleat http://scobleizer.com/ has a Twitter account and over 1000 friends. He's been asking his friends questions - and getting 1000 replies. Think of how blog posts and comments and trackbacks work - but on steroids. Instead of waiting a day or so for other thoughts, with Twitter you get them within the hour, tops. Setup correctly, that could prove to be an amazing "collective brain current awareness" database that you could tap at any time.

- Posts can link to interesting news stories about literacy or about libraries. When appropriate, the posts can link to a library's own website and blog for more in-depth information.

- Read latest News: Twitter makes it easy to quickly check, read, and update news and latest information. Many major news sites like CNN, BBC have Twitter feeds.

- Share a tip on finding or accessing information online or in the building: Spread the knowledge of your learning with others. If you've found a website that has specific resources or data, send a tweet and let everyone know.

- Use latest technologies \& Tool: Libraries were always open to implement new technologies. Knowing technological innovations will always give a added advantage, even if it is not apparent at the moment. Knowing and using the technology will be easier to adapt in long run.

\section{- Book an Appointment with Library Staff}

\section{Findings}

Twitter is gaining popularity as an efficient communication tool in U.S. libraries. The objectives of the study are realized and the hypotheses are verified. The final results of the study are:

1. Hypothesis 1: U.S. Libraries are active in using Twitter to develop their user community.

2. The above hypothesis is proved because in less than 5 years time as many as more than 800 U.S. libraries have their Twitter accounts. 
3. Hypothesis 2: U.S. libraries use Twitter to provide alert and current awareness services to their users. The above hypothesis is proved. Twitter is mostly used for current awareness or alert services in U.S libraries.

4. Hypothesis 3: Library Twitter accounts are not followed by encouraging number of followers.

In fact this hypothesis is proved to be correct, as compared to number of followers of celebrity Twitter accounts the followers of library Twitter accounts are very few. For example, as on November 29, 2011, Lady Gaga [15] has 16,454,037 followers and Library of Congress that has 306,524. Justin Bieber [16] has 14,962,839, Katy Perry [17] has 12,513,454, Kim Kardashian [18] has 11,568,198 and Barack Obama [19] has 11,346,842. Whereas, Library Twitter accounts, even in knowledge society, have few hundred thousand followers only.

\section{Discussion}

In the present information society and emerging knowledge societies the library and information centers prove to be essential in social and individual activities. Further, in the digital era the library and information centers are without any walls. That means their user group may extend to the world over. Under such circumstances ideally there should be phenomenal increase in the size of library user group. Consequently the number of followers for a libraries Twitter account also should be large. But on the contrary the size of the library Twitter groups is in few thousands for the majority of the libraries. Majority of the libraries with Twitter accounts have less than 1000 followers. This shows that even in information society and knowledge societies, the information and knowledge centers do not have considerable following. However, the number of followers for library Twitter accounts is relatively encouraging if library Twitter accounts are not compared with the celebrity accounts.

There are many interesting services that can be extended to the scholars throughout the world by utilizing the modern Information Communication Technologies. For instance, The Library of Congress webcasts can be witnessed by anybody from any nook and corner of the world. The information about such programs can be provided through Twitter, e-groups and other social networks and networking tools. Thus the social networking tools like Twitter will be useful for disseminating current information to the library users and also others. In using the latest technologies U.S. libraries prove to be in the forefront, the study proves the same. The ways in which the U.S. libraries are using Twitter would give useful ideas for optimum utilization of the web tools like Twitter to the rest of the libraries in the world who are not utilizing such technologies, in spite of having the required infrastructure and access to the latest technologies.

\section{Conclusion}

Library and information centers as one of the key stakeholders in the development of human society should be proactive to serve the user community in anticipation of their information needs. Libraries have undergone total transformation from a mere storehouse of documents to a service library, online library, and virtual library. They are re-designated as technical information centers, learning resource centers, knowledge parks and so on. This means that libraries are gaining their due importance in the human society by utilizing community building technologies like Twitter. Libraries will be in a position to build their user communities and act as effective facilitator for knowledge sharing if they use the community building technologies. 


\section{Twitters}

1. Twitter. (n.d.). Wikipedia. http://en.wikipedia.org/wiki/Twitter

2. Barack Obama. http://Twitter.com/\#!/BarackObama (28.11.2011 9:07pm IST).

3. Twellow. http://www.twellow.com/ (29.11.2011 2:57pm IST)

4. Twitterleague. http://www.Twitterleague.com/ (29.11.2011 2:59pm IST)

5. David Lee King. http://www.davidleeking.com/2007/05/09/twittering-libraries/\#.T1yWG4FlW4 (11.03.2012 5:51pm IST)

6. Paul Stainthorp. http://paulstainthorp.com/2012/01/25/list-of-uk-university-libraries-ontwitter/ (11.03.2012 5:51pm IST)

7. Lindy Brown Blog. http://lindybrown.com/blog/2009/01/libraries-on-Twitter-updated-list/ (28.11.2011 8pm IST)

8. Library of Congress. http://Twitter.com/\#!//ibrarycongress (28.11.2011 at 7:15pm IST)

9. The New York Public Library. http://Twitter.com/\#!/nypl (28.11.2011 at 7:15pm IST)

10. USDA NAL. http://Twitter.com/\#!/National_Ag_Lib (28.11.2011 at 7:15pm IST)

11. Houston Library. http://Twitter.com/\#!/houstonlibrary (29.11.2011 3:14pm IST)

12. Rick Reo. http://www.scribd.com/doc/20769928/Rick-Reo-s-Twitter-Adoption-AssessmentTool (30.11.2011 8:04pm IST)

13. 100 Ways to Use Twitter In Your Library. http://acceleratedbachelordegree.org/100-ways-touse-Twitter-in-your-library/ (29 Nov 2011 3:19pm IST)

14. Brian Mathews. Journal of Web Librarianship Social Eyes, Volume 2, Issue 4 www.lib.jmu.edu/org/jwl/documents/socialeyes_Twitter_2-4.doc (29.11.2011 4:29 pm IST)

15. Lady Gaga. http://Twittercounter.com/pages/100 (29.11.2011 2:24PM IST)

16. Justin Bieber. http://Twittercounter.com/pages/100 (29.11.2011 2:26 PM IST)

17. Katy Perry. http://Twittercounter.com/pages/100 ( 29.11.2011 2:27 PM IST)

18. Kim Kardashian. http://Twittercounter.com/pages/100 (29.11.2011 2:29 PM IST)

19. Barack Obama. http://Twittercounter.com/pages/100 (29.11.2011 2:29 PM IST) 


\section{Biographies}

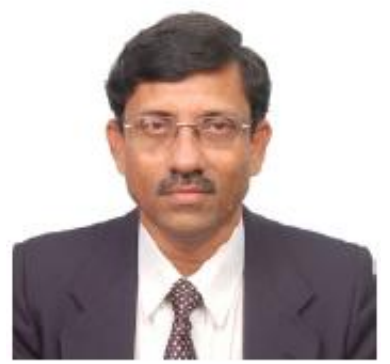

Dr. V. Vishwa Mohan, M.A., MLISc, Ph. D. (in Library and Information Science ), is presently Professor and Chairman, Board of Studies, Department of Library and Information Science, Osmania University, Hyderabad, India. He was born in the year 1958. He was also Head of the Department of Library and Information Science in the university for three terms. He was also Vice President and General Secretary of Indian Association of Teachers of Library and Information science. He has published over 60 research papers in the Indian and International journals and conference proceedings, three books and edited four books. He has been on editorial review board for two international journals and three international conferences. He has produced six Ph.Ds and twelve M.Phils. He is reachable at drvvm321@yahoo.com

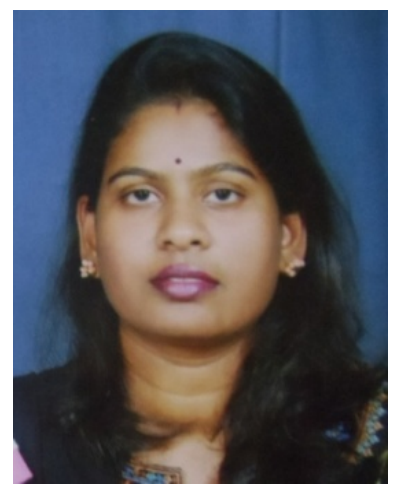

Ms. Achala Munigal M.A. (Philosophy), MLISc is presently working as Assistant Librarian in University College of Science, Saifabad, Osmania University. She has published 9 papers in National Seminars/Conference proceedings. AchalaMunigalRao@gmail.com \& AchalaMunigal@Osmania.ac.in. Twitter Handle:

@AchalaMunigalRao 